\title{
How Members of Parliament understand and respond to climate change
}

\begin{abstract}
Action on climate change, to meet the targets set in the 2015 Paris Agreement, requires strong political support at the national level. While the political and governance challenges of climate change have been discussed at length, there is little understanding of how politicians, as influential individuals within the political system, understand or respond to climate change. This paper presents findings from fourteen qualitative interviews with Members of the UK Parliament, to discuss how politicians conceptualise climate change, and their deliberations on whether or how to act on the issue. First, it reviews an interdisciplinary literature from sociology, political theory and science and technology studies, to investigate how politicians navigate their work and life. Second, it presents 'composite narratives' to provide four different MPs' stories. Last, it draws out conclusions and implications for practice. It highlights three crucial factors: identity, or how politicians consider the climate issue in the context of their professional identity and the cultural norms of their workplace; representation, how politicians assess their role as a representative, and whether proposed political action on climate is seen as compatible with this representative function; and working practices, how day-to-day work rituals and pressures influence the aims, ambitions and engagement of politicians with climate change.
\end{abstract}

Keywords: climate change, politicians, parliament, UK, identity, representation

\section{Introduction}

In a recent media interview, the British artist Anthony Gormley said that he despaired of politicians' inability to act on climate change. 'They are just not capable of long-term thinking', he said. 'We are sleepwalking into a massive human disaster' (quoted in Brown, 2015). Gormley is not alone in expressing these frustrations. Groups as diverse as Friends of the Earth, the OECD and the World Economic Forum have been critical of legislators' timidity on climate change (Bawden, 2015; Brown, 2015; Camberlain, 2013; Gurría, 2008). Are they right to lay the blame at the door of parliament, and specifically, on the action, or inaction, of politicians?

While the politics and governance of climate change has been much discussed across both sociology and political science (eg Biermann et al., 2012; Eckersley, 2004; Giddens, 2009; Johnson et al., 2014; Latour, 2014; Urry, 2011), there has been very little research directed at understanding how 
politicians understand and act upon the issue. A recent comprehensive review found no research into the views, values and motivations of practising politicians on these issues (Rickards et al., 2014). Yet elected politicians have crucial powers and responsibilities. Action by governments and parliaments is dependent upon politicians (amongst others) articulating a case, navigating conflicting interests and proposing responses.

This paper presents research exploring how politicians understand their role, and how they deliberate on an issue as complex as climate change. It starts from the assumption that climate change is a social and political issue, 'something that cannot be solved through a reliance on science and technology alone' (Carter and Charles, 2009:15). Thus sociological analysis is, as Urry writes, 'central to examining high carbon societies and climate change' (2009:84).

The research takes a similar approach to studies investigating public attitudes and motivations, such as Laidley's (2013) study of class differences in responding to climate change, Horton's (2003) account of the identity work of environmental activists, and Norgaard's (2006) investigation of climate understandings in a Norwegian village. The aim is not to supplant the more macro, structural accounts of climate governance and politics, but to enrich them through enhanced understanding of the motivations and outlooks of politicians - as crucial agents within this structure. In doing so, the research can improve practice, through helping scientists, policymakers and thirdsector advocates understand the political domain, and collaborate with politicians to develop workable strategies.

The paper begins with a discussion of the role played by national parliaments in climate action, following the 2015 Paris Agreement. Previous work from sociology, political theory and science and technology studies, which helps to explain politicians' motivations and outlooks, is then reviewed. The methodological approach is set out, and in particular, the use of narrative interviews. Findings are presented through four 'composite narratives', blended from fourteen interviews, telling four stories about how politicians navigate their working life in general, and climate issues in particular. Finally, conclusions and implications for practice are drawn out.

Governing the climate: From a global agreement to individual politicians 
The Paris Agreement on Climate Change of December 2015 was unprecedented. A record 195 countries agreed that "climate change represents an urgent and potentially irreversible threat to human societies and the planet... deep reductions in global emissions will be required' (UNFCC, 2015:1). While providing a framework for international co-operation, under the Agreement, each state is responsible for developing its own plan, called a 'nationally determined contribution', to contribute to the overall goal of limiting climate change to between $1.5^{\circ} \mathrm{C}$ and $2^{\circ} \mathrm{C}$ rise in global average temperature. Following Paris, therefore, attention has shifted to the level of the nation-state, and the process of drawing up strategies compatible with the Paris Agreement.

The UK already has statutory targets on carbon reduction, enshrined in the 2008 Climate Change Act. This Act sets five-yearly carbon budgets, leading to an $80 \%$ reduction in emissions from 1997 levels by 2050, overseen by the independent Committee on Climate Change. However, the means by which this goal will be reached are not clear. Targets need to be met through policies and action to reduce emissions in energy, transport, buildings and land use, for example. The Committee recently criticised government for a socalled 'policy gap' (Committee on Climate Change, 2016:3), saying that further policies are required if the targets are to be met. Responsibility for meeting the targets lies with Parliament, an institution consisting of 650 individual MPs, working within a context of established and evolving norms, procedures and rituals (Lovenduski, 2012).

\section{The life and work of a parliamentarian}

Though there is little research into the specific question of politicians' treatment of climate change, previous work offers insights into how politicians and others understand their role and navigate their working life. Below, three different approaches to this question are briefly reviewed: first, sociological investigations of parliament, looking at questions of identity in particular; second, research from political theory examining the representative role of politicians; and third, work from science and technology studies on the day-today working practices of individuals within institutions.

Identity: The social world of politicians

The ways in which individual outlooks and actions are conditioned by social and cultural contexts have long been studied by sociologists of identity (for a review see Lawler, 2014). Studies on gender in the House of Commons (Lovenduski, 2012; Malley, 2012; McKay, 2011; Puwar, 2004) demonstrate 
that the norms and rituals of parliament condition and constrain action. New institutionalist thinkers refer to this as a 'logic of appropriateness' (Chappell, 2006:223). Institutions like Parliament should be seen, they argue, as 'collections of interrelated rules and routines that define appropriate actions.... When individuals enter an institution, they try to discover, and are taught, the rules' (Chappell, 2006:161; see also Douglas, 1986; Lewis and Steinmo, 2012).

In a similar vein, Puwar (2004) draws on the work of Bourdieu in a study of female and ethnic minority politicians. Puwar argues that there are strong, yet implicit, norms governing life in the House of Commons. The 'habitus' or lifeworld of politicians, she argues, is implicitly gendered and racialised, yet white male politicians feel themselves to be neutral or unmarked. Puwar writes that 'there is a behavioural male norm and women are under assimilative pressures to conform to that norm' (1997:100).

If politicians reject these norms, they risk damaging their social capital. Puwar stresses the importance of social capital - forging links with others who provide support and endorsement. She describes 'circles, competing and overlapping, of mutual admiration... The higher you rise, the more you are party to the mechanisms of affirmation' (1997:120). Caroline Lucas' (2015) account of entering parliament as the sole Green Party MP is striking, in that the isolation Lucas feels is not just political, but personal and social too.

From this research, it is clear that, to investigate how politicians understand climate change, it is necessary to study individuals' implicit or explicit 'identity work', and the dynamics between individuals and organisations.

\section{Representation}

For politicians, however, it is not just the relationship between the individual and the organisation that matters. Politicians are also representatives, with relationships and responsibilities that go beyond the immediate confines of their institution. The relationship between the representative and those they represent is complex, and the subject of much debate in political theory, from the Ancient Greeks through to Rousseau and beyond (Dobson and Hamilton, 2016; Mansbridge, 2003; Urbinati and Warren, 2008). Recent work by Michael Saward conceptualises representation not as a static fact, but as a dynamic relationship between representatives and represented. Under this formulation, the representative makes a claim to representation, which can be accepted or rejected by constituents. Saward writes that representatives: 
Make claims about themselves and their constituents and the links between the two; they argue or imply that they are the best representatives of the constituency... They may well be 'agents', as representatives are conventionally understood, but equally or more importantly they are 'actors', makers of claims.' (Saward 2006:302)

The conception of representation as a negotiated claim links back to the first factor discussed above: that of identity. In this light, a crucial part of a politician's identity is the constant affirming and reaffirming of a representative claim, in order to show colleagues and publics alike that they are carrying out their role appropriately. Thus politicians speaking and acting on climate change must construct a 'representative claim' to justify their proposed actions, and to show why and how they are in the interests of the represented.

\section{Working practices}

It is not just abstract concepts of identity and representation which govern the working life of politicians. A third factor is the constraint placed upon them by the day-to-day practice of politics.

Ethnographies of parliament and government (Crewe, 2015; Rhodes, 2011) demonstrate that politicians spend their days in a fast-paced blur of meetings, actions and reactions. Work in science and technology studies demonstrates that everyday practices, whether in a laboratory or in Parliament, have a strong influence over the definitions of aims or ambitions (Latour, 1987). Fujimura's (1987) ethnography of scientists in a cancer laboratory reveals that scientists must constantly work to 'achieve alignment' between the day-to-day tasks they carry out, the wider environment of the laboratory; and the expectations of colleagues, sponsors and other actors. Whilst scientists state their aims in terms of the scientific breakthrough they are trying to achieve, these aims are constantly adapted and negotiated in the light of day-to-day pressures and constraints. Fujimura argues that, through this process of 'tinkering', aims and ambitions get remoulded into 'do-able problems', manageable within the confines of their institutional setting.

Applying this analysis to parliament, the day-to-day working life of politicians should be expected to influence their broader aims and ambitions. Analysis of political speech on climate change (Willis, 2017) demonstrates that politicians attempt to 'tame' climate change, presenting it as a more manageable issue than may be the case. It is thus essential to develop an understanding of what 
politicians regard as 'realistic'. Do politicians craft 'do-able problems' for themselves, and by doing so, effectively rule out 'un-do-able problems', which are too big, too complex or too different?

\section{Developing an understanding of politicians' deliberations on climate} These insights suggest that the ways in which politicians respond to climate change is complex and situated, influenced by social norms and political understandings. When politicians assess climate change, it is not simply a case of taking evidence and 'translating' it into appropriate governance mechanisms. Scholars of science and technology studies have long criticised the notion that science can be straightforwardly 'translated' (Wynne, 2010). Instead, the challenge is to understand the 'complex ways in which the construction of stable knowledge interprenates with the formation of core elements that stabilize society: identities, institutions, discourses and representations, among others' (Jasanoff, 2010:236). The aim of the research presented here, then, is to examine how politicians understand 'climate change', as a scientific, social and political phenomenon; and how this influences the way in which policies are developed and implemented.

\section{Methodology}

The aim of this study, as described above, is to supplement accounts of climate politics and governance with a deeper understanding of a crucial set of people in this debate: politicians. Thus the interviews were designed to elicit personal stories, drawing on Riessman's (2008) narrative method, in which participants are encouraged to tell the story of their work and life. The narratives that interviewees choose, the language and style they use, and the way that they conduct themselves are all significant. As Reissman writes in describing narrative research, 'narratives do not mirror, they refract the past... narratives are useful in research precisely because storytellers interpret the past rather than reproduce it as it was.' (2005:6)

The interviews were explicitly presented as collaborative, a joint investigation by the researcher and the researched (Morris, 2009; Oakley, 1988). As the interviewer, I was already known to most of the interviewees, having worked with the think tank Green Alliance, running workshops for MPs to discuss issues of environmental strategy. I did not present myself as an impartial academic, but as an inquirer and collaborator. Interviewees understood that one of the purposes of the study is to find ways to better support politicians in their work on climate change. 


\section{Research process}

MPs from three political parties in the UK House of Commons, Labour, Conservative and Liberal Democrat, were interviewed between February and June 2016. The interviews took place just after the conclusion of the Paris Climate Agreement; this was mentioned by some interviewees. All interviews took place before the EU Referendum on 23 June, though the referendum campaign provided a backdrop for discussions. MPs were recruited through an invitation setting out the collaborative nature of the project, as a joint initiative between [information removed for anonymity]. 22 MPs were approached, to secure the 14 interviews. Participants were selected to provide a balance of age, gender, political party, seniority and length of time served as an MP (see Table 1).

Participants' previous involvement in the issue of climate change was investigated. There was a wide spectrum of involvement, as evidenced by participation in events or speeches. Known 'climate sceptic' MPs (defined as those who publicly state that they do not accept the scientific consensus, as represented by the Intergovernmental Panel on Climate Change (IPCC, 2014)) were not approached. This is because the research question focuses on how MPs try to understand and act on climate change, rather than examining the reasons for rejecting the issue altogether. Although this is an interesting and important question, a different research strategy would be needed for this group. Though climate sceptics are influential, they are small in number, with only five MPs out of 659 voting against the Climate Change Act in 2008.

\begin{tabular}{|l|l|}
\hline Table 1: Interviewees' background and experience \\
\hline Gender & $\begin{array}{l}9 \text { male, } 5 \text { female (reflecting gender balance of Parliament } \\
\text { as a whole) }\end{array}$ \\
\hline party affiliation & 6 Conservative, 6 Labour, 2 Liberal Democrat \\
\hline time served as MP & $\begin{array}{l}\text { Between 1 and 19 years' work as an MP; mean = 6.4 } \\
\text { years }\end{array}$ \\
\hline current status & $\begin{array}{l}8 \text { sitting MPs; 6 former MPs, who left office in 2010 or } \\
2015\end{array}$ \\
\hline Seniority & $\begin{array}{l}4 \text { interviewees had served in government; 2 had served } \\
\text { on the opposition frontbench. 8 were backbenchers, most } \\
\text { with experience on Select Committees. }\end{array}$ \\
\hline $\begin{array}{l}\text { record on climate } \\
\text { change issues }\end{array}$ & $\begin{array}{l}\text { 7 with some record of activity on climate change issues } \\
\text { (judged through speeches in Westminster and } \\
\text { elsewhere); 7 with little or no activity }\end{array}$ \\
\hline
\end{tabular}


participants were not asked for additional demographic data, eg age or ethnicity

Interviews were semi-structured, and designed to be informal, with a focus on eliciting narrative from the participant. In the first part of the interview, I asked participants to reflect on the way that they work, including what issues they work on and why; and the influences and pressures upon them. I then asked questions specifically on climate change: the extent to which the issue is discussed in Parliament and how it is discussed; and whether and how they work on the issue. This basic framework was used for all interviews, though, in the spirit of narrative research (Riessman, 2008), the interview was conducted as a conversation, and emphasis varied. While the interviews were certainly collaborative, I challenged interviewees when I felt that this would aid reflection. Interviews were audio recorded and transcribed by the researcher. Ethical protocols, anonymity and consent were discussed with each participant.

Analysis and presentation of data: The use of composite narratives Interview data was transcribed and analysed through coding using NVivo software, and through critical reading of the scripts. The overall picture thrown out by the interview data was both more tangled and richer than anticipated. 'Standard' categories, such as party affiliation, social background, gender, age and previous experience all played a part, as expected from previous research (see, for example, Carter (2013) on party strategies; and research described earlier (eg McKay, 2011; Puwar, 2004) on gender). However, the picture that emerged did not show clear-cut distinctions along these lines, but a complex web of influences, moralities, strategies, assumptions and practicalities. Each individual could be seen to navigate their working life within this web, and, whereas each web was unique, some considerations were common to all - such as the issue of how each politician understands their role as a representative, as discussed below.

Thus the interviews presented a methodological challenge: how to do justice to the complexities of individual motivations and outlooks, whilst drawing out more generalised learning and understanding; or, in the words of STS scholar John Law, how to deal with 'mess', and finding ways 'to keep the metaphors of reality-making open, rather than allowing a small subset of them to neutralise themselves and die in a closed, singular, and passive version of out-thereness' (Law, 2004:139). 
Above all, the data asked for a form of presentation that conveyed the richness of each individual interviewee's account. Yet this posed a further challenge: that of anonymity. All participants spoke anonymously, and this was crucial in building a clear picture of their private deliberations. In this context, assuring anonymity requires a more robust approach than just changing names (Saunders et al., 2015; Tolich, 2004). Politicians, as public figures, are identifiable through a combination of factors such as age, time in office, constituency, party affiliation, professional or family background and so on.

These two considerations: first, the need to convey the richness and complexity of individual accounts; and second, the need to ensure anonymity, led to the decision to present the data as a series of 'composite narratives'. Using this approach, several individual interviews are combined to tell a single story. This approach, though rare, has been used when researching complex issues when anonymity is crucial, such as Piper and Sikes' (2010) study of teacher-pupil relationships.

Four composites were created from the data: 'David', a relatively new MP, who speaks regularly on the need to address climate change; 'Jonathan', also new to Parliament, who is less confident about speaking out; 'Paul', a more experienced politician with a frontbench role, who tries to find strategies to work on climate issues that resonate with his colleagues and constituents; and 'Stephanie', a veteran ex- minister, who is concerned with the practicalities of achieving political and legislative change.

These accounts are stories, not fictions (Smart, 2010) in that each description is based solely on interview data, and all quotations come directly from interviews. The only modification is to present data from several interviews as if it were from a single individual. The stories mix interviewees from both genders, though in order to tell the story straightforwardly, a gender has been assigned to each narrative - one female, three male, roughly representing the gender split of the Commons ( $71 \%$ male). Party affiliations have not been ascribed to each story. As discussed above, political outlook is crucial to each politician's strategy and motivation, but the data did not reveal clear-cut distinctions along party lines. At the beginning of each narrative is a short description of the interviews that the composite is based on.

The interview data could, of course, have been combined in different ways, to create different composites. Indeed, different combinations were considered 
and explored. The final composites were chosen as they were felt to convey the range of views and positions revealed by the data, and to provide contrasting accounts of outlook and strategy. To borrow from John Law again, the aim is a 'complex and performative sense of social inquiry' in which 'methods are never innocent... they enact whatever it is they describe into reality' (Law and Urry, 2004).

\section{Deliberating on climate change: Four stories}

\section{David}

'David' is a composite of three interviewees, one Labour, one Conservative and one Liberal Democrat, with a mean of 3.7 years in office. One interviewee had recently taken a role as a spokesperson for their party, the other two were backbenchers.

David has been in Parliament six years. He is a backbencher, and sits on a Select Committee. He is forthright, and a champion of climate issues. He points out to me that where we're sitting, in the House of Commons beside the River Thames, may well be under water in a few years' time. He calls climate change 'catastrophic', and thinks that might be why some of his colleagues don't want to talk about it:

'I think the majority of MPs recognise that climate change is manmade, is happening and is going to have catastrophic consequences, but it's so scary in some ways, maybe they don't want to think about it. It's just such a big issue.'

David tries to speak about climate change at every opportunity, both in Parliament and in his constituency. He asks questions about climate issues in debates; he puts forward amendments which alter legislation in support of climate action; and he goes to meetings hosted by environmental groups.

David feels that his commitment has come at a price. Like every MP I speak to, he says that climate change is not discussed much in the Commons. He thinks his colleagues see him as a 'freak', and that speaking out on climate is a 'career-limiting move'. Though he doesn't set out to be difficult, and would like to be promoted, it is important to him to speak up for what he believes in. However, he thinks about how to present issues in ways that might appeal: 'I'm happy to use an economic argument if that means that more people will come on side.... I change the language to be much, much less extreme'. 
As a relatively new MP, David says he needs to focus a lot of his attention on his constituency. He feels a responsibility to the people he represents, and wants to stand up for his local area. This takes up a lot of his time. Like nearly all the MPs I interview, he says that he's never asked questions about climate change. 'I've knocked on thousands of doors, and had thousands of conversations with voters, and I just don't have conversations on climate change'. Nevertheless, he says 'I do feel I have a mandate to act on it', and finds ways to talk about it. He uses speeches in his constituency to 'highlight the things that I care about', including climate change. He works with local environment groups, like Friends of the Earth and Greenpeace, though he is critical about how strident they are. They are like the Englishman abroad, he says; 'If you don't understand me, l'll shout louder'.

He thinks much discussion of climate change is too abstract and distant from voters: 'They've never been to Bangladesh, they've never met a polar bear... they're like, "yeah, ok, whatever"'. Instead, he tries to make a case for lowcarbon jobs, preventing floods and so on, building climate change into the discussions as he goes.

Despite his commitment to the issue, David says it is important to be realistic about what can be achieved:

'Politicians like to have campaigns that they can win. Then they can do that press release: "I campaigned for $\mathrm{x}$, and I got $\mathrm{x}$, and l've delivered for you." And you can't say "I've campaigned to stop climate change. And now climate change is fixed, and l've delivered for you." It's never going to be a press release that anyone's going to put out.'

Jonathan

'Jonathan' is a composite of three interviewees, one Labour, two Conservative. Two had served one year as an MP; one had six years' experience. One had a role as a spokesperson for their party; the other two were backbenchers.

Jonathan is new to Parliament. Elected a year ago in a marginal seat, he feels that his position is precarious. He is just starting to find his way around the Commons, saying that 'there isn't really any training in being an MP'. He comments that the working ethos is 'totally individualistic, not collegiate', with each MP having to steer their own way through their working life. Knowing I have worked with politicians, he asks me for my opinion: 'Everyone appears 
to do it differently depending on their circumstances, so there's no model, I wouldn't say. Who do you think's doing it well? What do you see?'

Jonathan is cautious about being 'pigeonholed'. For example, he has spoken several times in parliament about a particular health condition, but worries that colleagues will see him as the person who 'keeps banging on about [the condition]. Whereas you want people to think of you as, oh you can go to him with anything.' He is critical of strategies used by MPs like David, who speak stridently about the causes they believe in. 'You can't just go steamrollering in, although some people have done that, and they've made themselves very unpopular.... So you have to tread really carefully'.

Jonathan has not spoken much about climate change, in Parliament or in his constituency. He says 'my priority is to stand up for my constituency'.

Jonathan sees climate change as an abstract, long-term issue, which makes it hard to talk about. 'Telling people about the long term is a hard sell, you know it's not going to get in the local paper above [a story about how] one village has broadband and the other doesn't.' Every decision he makes, his constituency comes first. He tells me this is because of the UK's electoral system. Jonathan compares his marginal constituency with colleagues who have safe seats:

'There's a sort of a luxury that comes with a safer seat, you can say "Well ok well I care about, whatever issue," and make that your mission in life to change the world on one particular issue. Whereas when you're in a more marginal seat... you feel like you have to be doing a little bit of everything.'

Jonathan describes a particular group within his constituency as 'retired, intelligent and affluent'. Such people like to make their views known to their local MP, he says, yet there is a danger in just listening to the loudest voices. He tries to make contact with people who would not think of approaching him. Of course, he wants their votes; but he also wants to make sure he is representing the interests of all his constituents, not just the campaigners and letter-writers.

\section{Paul}

'Paul' is a composite of four interviewees, three conservative and one liberal democrat. All had served either five or six years; three were backbenchers and one had a role as a Parliamentary Private Secretary. 
Paul has served two terms as an MP, and has a frontbench role. When I ask him why he ran for parliament, he says, "it sounds rather trite, but coming into politics was an exercise in wanting to make a difference. My previous work [in the public sector] had taught me that there was plenty wrong in society'.

Paul says that he sees climate change as a 'gut' issue. He has thought a lot about it, but worries that it does not motivate his colleagues. He says they are generally 'not naturally inclined to be so interested in this policy area' and that there is no pressure from party leaders to get involved. He sees limited value in trying to persuade colleagues, and tries to find other ways to make progress. He gives me his ideas for reforming transport and energy policy, but is adamant that such policies should be justified solely on economic and social grounds, and that reducing carbon emissions, or tackling climate change, should not be given as a reason for action. In short, he advocates climate policy by stealth. 'I don't use climate change as the word because I think it's just toxic now in politics', he tells me. 'As is the way in these issues which are contentious, you won't take people with you politically.'

Paul worries that too much focus on climate change risks alienating people both local people in the constituency, and fellow MPs. He says 'I think it is important not to be a climate change zealot'. He recently argued for better public transport in his local area, alongside a proposed road scheme. When I ask him whether he had talked about the carbon emissions from transport, he says 'I think if I had mentioned carbon emissions, there would have been a rolling of eyes and saying, "Oh here he goes again".' So he made his case in other ways. He is very deliberate in his choice of strategy, and in the words he uses.

He is pessimistic about the ability of parliamentary processes and mechanisms to bring about change. He tells me that he worried about this before he was elected, but 'I underestimated. There's no question I underestimated. The frustrations are much greater... it's a bunfight, nothing ever changes, you can become deeply cynical.' He says that how policy is designed 'ends up really mattering' and is more important than bold public statements. He mentions Bismarck's phrase: 'politics is the art of the possible'.

Paul has a different attitude to his constituents than David or Jonathan. He is not so strongly motivated by constituency work, he tells me. 'I enjoy the constituency stuff; it gives me a hell of a lot of information and knowledge 
which is of benefit to me here for the national stage. But ultimately, my job is here [in Parliament], it isn't there.' Though this attitude gives him more freedom to focus on the things that he sees as important, he is keen to point out that he is not dismissive of local views. He sees his constituency as a barometer of public opinion.

Paul talks about the possibility of profound change over time, using the example of equal marriage legislation to argue that change is possible through a combination of opinion shifts and careful policy. He worries, though, about moving too far, too fast. He says, "however much it might look like the leaders are making decisions, in a democracy they are polling public opinion, they are asking people about their priorities, they're experiencing, just in the course of doing their job, where public opinion is'. This complex balancing act, he says, is the core of democratic process. So no matter how urgent the issue, 'the idea that you can somehow ignore the electoral result when setting your expectations of what government might do is, I think, profoundly undemocratic.'

\section{Stephanie}

'Stephanie' is a composite of four interviewees, all from the Labour party, with a mean of 12 years' experience in parliament. Two had been junior ministers, and two had served in the Cabinet.

Stephanie has been in the Commons for three terms, and has served as a minister. She expresses her views readily, and speaks with the relaxed confidence of someone who has proven their worth. Though she talks about her constituency, it is clear that it doesn't have the same pervasive influence on as for younger or less experienced MPs. Neither is she as worried about what people think of her. When I tell her that other MPs are worried about being seen as outsiders if they make the case for action on climate change, she is surprised and even dismissive: 'There's no argument for staying quiet on any of this. You've got to speak out'.

Stephanie sees herself as a pragmatist, and says that others' expectations are unrealistic. 'The punters, the populace think that the politician, the prime minister for example, is all-powerful. Actually, they absolutely are not. I'm not saying they have no power, but they can't just do it.' This isn't an excuse for doing nothing, she says, but is instead a plea to focus on the practical steps necessary to achieve change. 
This view is central to her argument about how to tackle climate change. It's not enough, she says, for politicians to be convinced of the science: 'Even if all the Cabinet today were completely persuaded, the question then of what you do about it, becomes a difficult and problematic issue.' She was in Parliament when the 2008 Climate Change Act was passed, and like the vast majority of MPs, voted for the legislation. She doesn't remember it being discussed much, though: 'The big issues were more around terrorism, antiterrorism legislation, tax rates, and smoking in public places... I remember it going on in the background'. She thinks that the fact that there was a strong consensus might have meant that it was discussed less, saying that if 'you take it out of the day-to-day of political conflict, you shouldn't be surprised that people aren't talking about it.' Stephanie describes the group of politicians working directly on the Bill as 'the obsessives.... I know it's offensive to use the term obsessives'. For her, she says, climate change 'probably falls into the basket of general progressive issues that sound good to ensure'.

I ask Stephanie more about this, talking about the likely impacts of climate change. She tells me that I'm missing the point. Just stating the problem, without regard to practical steps that can be taken, is counter-productive. 'The argument you've just made, that we're in a qualitatively different situation than we've ever been in history, in my opinion doesn't help the argument at all.' For the same reason, she criticises environmental organisations: 'motivation isn't about just a set of beliefs, it's about an ability to implement... this is a criticism l'd make of many of the green organisations, you just say it's all very worthy but what the fuck can you do?' Instead, she wants to focus on tangible objectives, promoting measures that improve local areas, like encouraging walking and cycling, creating jobs in the renewables industry, and so on.

Though Stephanie is less focussed than other interviewees on the views of her constituents and public opinion, she does also ask how realistic it is to expect significant change on an issue that barely features in public or media debate. Following the recession, she says, it has 'died' as an issue. Neither is it discussed much within her party: 'If either your party membership or the public are not flagging it up consistently as one of their top concerns or priorities, that is the issue.' She is keen to explore changes to the practice of politics that could enable a more constructive debate between parties on climate change. 'It's the ultimate challenge to politics, isn't it?' she says.

\section{Conclusions and implications for practice}


As the narratives show, the ways in which the politicians in this study approach climate change is influenced by their understanding of the scientific evidence, but also by their professional identity; their conception of their role as a representative; and the way they navigate the day-to-day realities of life as an MP. Each of these are discussed in turn, below. Based on this analysis, some implications for practice are drawn out.

\section{Climate change and identity}

David's characterisation of himself as a 'freak', Jonathan's criticism of colleagues who become identified by a single issue, and Paul's careful strategies to avoid being labelled a 'climate change zealot' all point to a strong awareness of social and cultural norms within Parliament, which individuals compare themselves against. This confirms results of previous studies (eg Puwar, 2004). The pressures are particularly acute for new MPs. Whilst Stephanie, given her seniority and experience, says that she does not feel the need to conform, her description of the 'obsessives' advocating for climate change contributes to the sense that it is an outsider's issue. Taking an active role on climate does not fit current institutional norms. Thus politicians must choose to either keep quiet, like Jonathan, or develop strategies that they feel will not negatively affect their reputation or legitimacy. They may even, like Paul, do this by deliberately not mentioning climate change while championing policies which they feel to be appropriate solutions to the problem. The alternative is David's strategy of saying exactly what he thinks, even though he feels that it casts him as an outsider and could limit his career. This matters not just because it might affect David's career prospects, but also because, if climate advocates are less influential within the mainstream of each party, the issue will receive less attention.

This and other evidence (eg Hulme, 2009) shows that, for climate, the messenger is as important as the message. Politicians will feel more comfortable speaking out on climate change if they hear others do the same. More vocal support from party leaders and elders would help, as would advocacy from outside parliament - for example, from business, civil society organisations and the scientific community.

Making a representative claim on climate change To what extent can politicians reconcile action on climate change with their 'representative claim', as discussed above? Each politician sees their representative role differently, and constructs their claims differently. Some, like Paul, see themselves as primarily a representative at the national level, 
with their constituents informing, but not prescribing, their stance in parliament. Others, like Jonathan, see their job as representing their local area as faithfully as possible. Within the group of interviewees, newer MPs were more likely to forge an account of their legitimacy based on their ability to respond to the demands of the people they represent.

This set of interviews suggests that politicians feel little pressure from those they represent to act on climate change. Nevertheless, some politicians, like Paul and Stephanie, find ways to connect climate change to issues of importance to those they represent - through making the link to job creation, better transport systems and so on. This can be seen as constructing a 'representative claim'. However, for such a claim to work, it must be accepted by those being represented. Hence the warnings of some MPs that their mandate for action on climate change is limited, and Paul's explicit warning that to ignore the electoral result is 'profoundly undemocratic'.

Thus the mandate for action on climate is not straightforward. Politicians need to playing a mediating role between the scientific consensus embodied in the Paris Agreement, on the one hand, and current public views and demands, on the other, by building a 'representative claim' that action on climate is in the democratic interest. One possibility would be through the use of deliberative or collaborative approaches to politics at a local level (Dryzek, 2002), whereby Members of Parliament, together with local politicians and other stakeholders, used deliberative processes to discuss climate strategies which would benefit local areas. This could follow the model of participatory budgeting, for example (Davidson and Elstub, 2014).

It may be that the UK's constituency-based electoral system acts as a block to action on climate change; comparative research with politicians in other legislatures with contrasting electoral systems would help to identify whether this is the case. More fundamentally, the interviews highlight tensions between different time horizons, with politicians elected for five years or fewer, whilst being asked to take responsibility for issues playing out over decades. Sociological accounts of futures (Adam and Groves, 2007; Urry, 2016) stress that contestation over the future affects and is affected by current concerns. Some legislatures, including Hungary, Finland and Wales, have made this link explicit, by creating institutions such as an 'ombudsperson' or 'commissioner' tasked with representing future generations.

Is climate change a 'do-able problem'? 
With her long experience of politics, Stephanie puts a particular emphasis on the need to focus on practicalities, and is critical about politicians and others who take a moral stand on an issue without offering actionable solutions. David, too, reminds us that politicians need to show results; Paul calls for realism about how difficult genuine reform is. Coupled with the pressures of day-to-day life in the Commons, it is clear that politicians feel that they need to craft 'do-able problems', to borrow Fujimura's (1987) phrase, out of the climate agenda. They seek ways of working on climate change which fit the working practices of parliament and the institutions of policymaking. Interviewees gave examples of possible approaches, including reducing emissions from the transport sector through promoting public transport, incentivising renewable energy, policies to improve the energy efficiency of housing, and using industrial policy to promote low-carbon innovation strategies. These all provide a way for politicians to support bounded and achievable action on climate change, measures which fit within the established culture of politics and policymaking.

The question is whether action on climate change can indeed be crafted as a series of 'do-able problems'. Is it possible to envisage a set of responses which are politically and practically feasible, whilst significant enough to meet the statutory carbon targets laid down in the UK's Climate Change Act? The analysis of Parliament's independent adviser, the Committee on Climate Change, suggests that it may be (Committee on Climate Change, 2016). However, more radical critics maintain that meaningful action is incompatible with the global economic system, and that far-reaching changes to our economy and society are necessary (Jackson, 2011; Klein, 2015). Whilst this is not a view that politicians in this study held, four out of the fourteen interviewees did single out climate change as an issue different to others, in that it threatens the benign environmental conditions that have underpinned our society for many thousands of years (Clark, 2011). David's comment that the House of Commons may one day be under water is a stark illustration of this.

Politicians need to perform a difficult juggling act: articulating the scale and significance of climate change, while also crafting and building support for tangible, achievable projects and initiatives to address it. Recent evidence from city-scale action on climate may point the way (Bulkeley et al., 2014). In recent years, however, the UK's climate strategy has been national in focus, with no targets or responsibilities being given to local areas. A reinvigoration 
of local action on climate change may help to make the issue seem more tangible and 'do-able'.

The research presented here indicates that action on climate change poses considerable challenges for politicians. In short, even if they are convinced of the case for action, they find it difficult to craft responses that are credible, manageable and popular, within current institutions and systems of governance. However, there is much that could be done to support politicians in their crucial role on this issue.

Adam, B., Groves, C., 2007. Future matters: action, knowledge, ethics. Brill, Leiden; Boston.

Bawden, T., 2015. Climate change activists blame Government for 'colossal failure' to make global warming a national priority. The Independent Newspaper, 5 January.

Biermann, F., et al., 2012. Transforming governance and institutions for global sustainability: key insights from the Earth System Governance Project. Current Opinion in Environmental Sustainability 4, 51-60.

Brown, M., 2015. Gormley climate change artwork shown for first time in the Guardian. The Guardian, 6 March.

Bulkeley, H., et al., 2014. Low-carbon Transitions and the Reconfiguration of Urban Infrastructure. Urban Studies 51 (7), 1471-1486.

Camberlain, J., 2013. Climate Change, Lack of Political Will Leading to 'Global Perfect Storm' Common Dreams website http://www.commondreams.org/news/2013/01/08/climate-change-lackpolitical-will-leading-global-perfect-storm-report (accessed 12.9.16).

Carter, B., Charles, N., 2009. Society, nature and sociology. The Sociological Review 57 (s2), 1-20.

Carter, N., 2013. Greening the mainstream: party politics and the environment. Environmental Politics 22 (1), 73-94.

Chappell, L., 2006. Comparing Political Institutions: Revealing the Gendered 'Logic of Appropriateness'. Politics \& Gender 9 (2), 223-235.

Childs, S., 2004. A feminised style of politics? Women MPs in the house of commons. British Journal of Politics and International Relations 6 (1), 3-19.

Clark, N., 2011. Inhuman nature: sociable life on a dynamic planet. SAGE, Los Angeles ; London. 
Committee on Climate Change, 2016. Meeting Carbon Budgets - 2016 Progress Report to Parliament. Committee on Climate Change.

Crewe, E., 2015. The House of Commons: An Anthropology of MPs at Work. Bloomsbury, London.

Davidson, S., Elstub, S., 2014. Deliberative and Participatory Democracy in the UK. British Journal of Politics \& International Relations 16 (3), 367385.

Dobson, A., Hamilton, L., 2016. Review Exchange: Representation and political theory. European Political Science (advance online publication)

Douglas, M., 1986. How Institutions Think. Syracuse University Press.

Eckersley, R., 2004. The green state: rethinking democracy and sovereignty. MIT Press, Cambridge, Mass.

Fujimura, J.H., 1987. Constructing 'Do-Able' Problems in Cancer Research: Articulating Alignment. Social Studies of Science 17 (2), 257-293.

Giddens, A., 2009. The Politics of Climate Change. Polity, Cambridge.

Gurría, A., 2008. Climate Change: A Matter of Political Will. Speech by Angel Gurría, OECD Secretary General, OECD Forum, June 2008. http://www.oecd.org/env/toolsevaluation/climatechangeamatterofpoliticalwill.htm [accessed 5.3.2017]

Horton, D., 2003. Green distinctions: the performance of identity among environmental activists. The Sociological Review 51 (2), 63-77.

Hulme, M., 2009. Why we disagree about climate change: understanding controversy, inaction and opportunity. Cambridge University Press, Cambridge, UK.

IPCC, 2014. Climate change 2013: The physical science basis. Cambridge University Press, New York.

Jackson, T., 2011. Prosperity without growth: economics for a finite planet. Earthscan, London.

Jasanoff, S., 2010. A New Climate for Society. Theory Culture Society 27 (23), 233-253.

Johnson, E., et al., 2014. After the Anthropocene: Politics and geographic inquiry for a new epoch. Progess in Human Geography 38 (3), 439456.

Klein, N., 2015. This changes everything: capitalism vs. the climate. Penguin, London.

Laidley, T., 2013. Climate, class and culture: political issues as cultural signifiers in the US. Sociological Review 61 (1), 153-171.

Latour, B., 2014. Agency at the Time of the Anthropocene. New Literary History 45 (1), 1-18. 
Latour, B., 1987. Science in action: how to follow scientists and engineers through society. Harvard University Press, Cambridge, Mass.

Law, J., 2004. After method: mess in social science research, International library of sociology. Routledge, London.

Law, J., Urry, J., 2004. Enacting the social. Economy and Society 33 (3), 390410.

Lawler, S., 2014. Identity: Sociological perspectives. Polity Press, Cambridge.

Lewis, O.A., Steinmo, S., 2012. How Institutions Evolve: Evolutionary Theory and Institutional Change. Polity 44 (3), 314-339.

Lovenduski, J., 2012. Prime Minister's questions as political ritual. British Politics 7 (4), 314-340.

Malley, R., 2012. The institutionalisation of gendered norms and the substantive representation of women in Westminster and the Scottish parliament. PhD thesis, University of Bristol.

Mansbridge, J., 2003. Rethinking representation. American political science review 97 (4), 515-528.

March, J.G., Olsen, J.P., 1984. The New Institutionalism: Organizational Factors in Political Life. American Political Science Review 78 (3), 734749.

McKay, J., 2011. 'Having it All?' Women MPs and Motherhood in Germany and the UK. Parliamentary Affairs 64 (4), 714-736.

Moir, E., Leyshon, M., 2013. The design of decision-making: participatory budgeting and the production of localism. Local Environment 18 (9), 1002-1023.

Morris, Z.S., 2009. The Truth about Interviewing Elites. Politics 29 (3), 209217.

Norgaard, K.M., 2006. 'We Don't Really Want to Know': Environmental Justice and Socially Organized Denial of Global Warming in Norway. Organization Environment 19 (3), 347-370.

Oakley, A., 1988. Interviewing Women: A Contradiction in Terms, in: Roberts, H. (Ed.), Doing Feminist Research. Routledge, London.

Piper, H., Sikes, P., 2010. All Teachers Are Vulnerable but Especially Gay Teachers: Using Composite Fictions to Protect Research Participants in Pupil-Teacher Sex-Related Research. Qualitative Inquiry 16 (7), 566-574.

Puwar, N., 2004. Space Invaders: Race, Gender and Bodies Out Of Place. Berg.

Puwar, N., 1997. Reflections on Interviewing Women MPs. Sociological Research Online 2(1). 
Rhodes, R.A.W., 2011. Everyday life in British government. Oxford University Press, Oxford.

Rickards, L., et al., 2014. Barriers to effective climate change mitigation: the case of senior government and business decision makers. Wiley Interdisciplinary Reviews: Climate Change 5 (6), 753-773.

Riessman, C.K., 2008. Narrative methods for the human sciences. Sage Publications, Los Angeles.

Riessman, C.K., 2005. Narrative Analysis, in: Kelly, N.,et al. (eds), Narrative, Memory and Everyday Life. University of Huddersfield, Huddersfield.

Saunders, B. et al., 2015. Anonymising interview data: challenges and compromise in practice. Qualitative Research 15 (5), 616-632.

Saward, M., 2006. The Representative Claim. Contemporary Political Theory 5 (3), 297-318.

Smart, C., 2010. Disciplined Writing: On the problem of writing sociologically. Working Paper. Morgan Centre, University of Manchester.

Swyngedouw, E., 2010. Apocalypse Forever? Post-political Populism and the Spectre of Climate Change. Theory Culture Society 27 (2-3), 213-232.

Tolich, M., 2004. Internal Confidentiality: When Confidentiality Assurances Fail Relational Informants. Qualitative Sociology 27 (1), 101-106.

UNFCC, 2015. Adoption of the Paris Agreement. UNFCC

Urbinati, N., Warren, M.E., 2008. The Concept of Representation in Contemporary Democratic Theory. Annual Review of Political Science 11 (1), 387-412.

Urry, J., 2016. What is the future? Polity Press, Cambridge, UK; Malden, MA.

Urry, J., 2011. Climate change and society. Polity Press, Cambridge, U.K.

Urry, J., 2009. Sociology and Climate Change. The Sociological Review 57 (2), 84-100.

Willis, R., 2017. Taming the Climate? Corpus analysis of politicians' speech on climate change. Environmental Politics 1-20.

Wynne, B., 2010. Strange Weather, Again: Climate Science as Political Art. Theory Culture Society 27 (2-3), 289-305. 